\title{
Methylation in oral cancer and pre-cancerous lesions (Review)
}

\author{
R. DÍEZ-PÉREZ ${ }^{1}$, J. CAMPO-TRAPERO ${ }^{2}$, J. CANO-SÁNCHEZ ${ }^{3}$, M. LÓPEZ-DURÁN ${ }^{1}$, \\ M.A. GONZALEZ-MOLES ${ }^{4}$, J. BASCONES-ILUNDAIN ${ }^{2}$ and A. BASCONES-MARTINEZ ${ }^{5}$ \\ ${ }^{1}$ School of Dentistry, UCM, Madrid; ${ }^{2}$ School of Dentistry, UCM, Madrid; ${ }^{3}$ Department of Medicine and Buccofacial \\ Surgery, School of Dentistry, UCM, Madrid; ${ }^{4}$ Department of Oral Medicine, School of Dentistry, University of \\ Granada, Granada; ${ }^{5}$ Department of Oral Medicine and Periodontology, School of Dentistry, UCM, Madrid, Spain
}

Received October 20, 2010; Accepted December 27, 2010

DOI: $10.3892 /$ or.2011.1205

\begin{abstract}
There is considerable interest in the analysis of epigenetic alterations in cancer, including oral cancer and pre-cancerous lesions. These processes affect or inactivate the functions of genes without altering their structure or sequence. One example is the methylation of the promoter region of some genes involved in cell cycle control. Knowledge of methylation patterns is very important for understanding the expression of genes in normal and pathological situations. This review provides an update on research into this issue in oral cancer and pre-cancerous lesions. A greater understanding of this epigenetic alteration could not only assist the diagnosis and prognosis of oral cancer but could also open up novel therapeutic approaches. The presence of methylation in specific tumour suppressor genes could modify their function and alter cell cycle control, so the patients could have an increased risk of developing cancer and also a higher degree of malignancy. The most frequently and extensively studied methylated genes in oral premalignant lesions are p16, MGMT, RAR $\beta_{2}$, E-cadherin and DAP-kinase.
\end{abstract}

\section{Contents}

1. Introduction

2. Concept of epigenetic alterations

3. Epigenetic alterations in oral cancer and pre-cancerous lesions: p16 $6^{\text {INK4a }}$, MGMT, DAP-kinase, RAR $\beta_{2}$, E-cadherin, other genes

4. Sampling for methylation study

5. Relationship with other tumours

6. Relationship with tobacco use

7. Relationship with progression and malignization

Correspondence to: Dr Antonio Bascones-Martinez, Department of Stomatology, Plaza de Ramón y Cajal 3, Ciudad Universitaria, 28040 Madrid, Spain

E-mail: antbasco@odon.ucm.es

Key words: hypermethylation, pre-cancerous lesions, oral squamouscell carcinoma, oral cancer, PCR, leukoplakia
8. Reversibility of methylation

9. Conclusion

\section{Introduction}

Cancer is the second cause of mortality in developed countries. Head and neck cancer represents 5-10\% of cases in Europe, where there is a rising incidence of oral cancer and associated mortality, especially among young populations (1). The most frequent oral cancers are oral squamous cell carcinomas (OSCCs) which are the most malignant tumours of the head and neck (2). This aggressive epithelial neoplasm is associated with severe morbidity and $<50 \%$ long-term survival, despite advances in surgical treatments and in radioand chemotherapy.

These cancers are occasionally preceded by potentially malignant (pre-cancerous) lesions, such as leukoplakia and erythroplakia. Epidemiological data from different countries over the past 30 years have shown prevalence of oral leukoplakia ranging from 1.1 to $11.7 \%$ (mean of $2.9 \%$ ), with prevalence among smokers ranging from 3.7 to $60.3 \%$ (3). Up to $10 \%$ of patients with leukoplakia have an invasive carcinoma (4), and the short survival of oral cancer on leukoplakias (only 30-40\% survival at 5 years post-diagnosis) makes prevention of this malignant transformation essential (5).

Tobacco (including smoked and chewed variants) is the prime cause of oral cancer worldwide and is estimated to be responsible for around 400,000 new cases every year. Betel nut chewing has been implicated in OSCC, leukoplakia and oral submucous fibrosis (progressive inflammation and fibrosis of connective tissue) (6). Other predisposing factors for oral cancer include alcohol use, gender, age and infection by human papillomavirus $(7,8)$.

\section{Concept of epigenetic alterations}

Carcinogenesis is a multistep process in which cells accumulate changes in their genetic material, giving rise to an alteration of cell function. Some of these changes can not be attributed to a DNA sequence modification (e.g. deletion or mutation) and are designated epigenetic changes. These are 
Table I. Genes whose methylation is related to head and neck cancer.

\begin{tabular}{|c|c|c|c|c|c|}
\hline $\begin{array}{l}\text { Type } \\
\text { of gene }\end{array}$ & Function & Action mechanism & $\begin{array}{l}\% \text { Methylation in } \\
\text { tumour lesion/ } \\
\text { pre-cancerous lesion }\end{array}$ & $\begin{array}{l}\% \text { Methylation } \\
\text { in saliva/ } \\
\text { healthy mucosa }\end{array}$ & Refs. \\
\hline $\mathrm{P} 16^{\mathrm{INK} 4 \mathrm{a}}$ & $\begin{array}{l}\text { Tumour suppressor } \\
\text { gene (regulates } \\
\text { cell cycle) }\end{array}$ & $\begin{array}{l}\text { Vital in } \mathrm{Rb} \text {-cyclin } \mathrm{D} \\
\text { pathway to maintain } \\
\text { retinoblastoma } \\
\text { protein }\end{array}$ & $\begin{array}{l}\text { 27/NR (HNC) } \\
\text { 47/NR (HNC) } \\
\text { 32.5/NR (HNC) } \\
\text { NR/44 (oral leukoplakia) } \\
\text { 39/29 (oesophageal c.) } \\
\text { 50.9/NR (OSCC) } \\
\text { 76/NR (OSCC) } \\
\text { 35/NR (OSCC) } \\
\text { NR/55 (severe dysplasia) }\end{array}$ & $\begin{array}{l}31 / \mathrm{NR} \\
79 / \mathrm{NR} \\
\mathrm{NR} / \mathrm{NR} \\
\mathrm{NR}^{\mathrm{a}} / \mathrm{NR} \\
\mathrm{NR} / 0 \\
\mathrm{NR} / 72.73^{\mathrm{b}} \\
\mathrm{NR} / \mathrm{NR} \\
87.5 / \mathrm{NR} \\
\mathrm{NR} / 0\end{array}$ & $\begin{array}{l}\text { Sanchez-Cespedes, et al (16) } \\
\text { Rosas, et al (18) } \\
\text { Hasegawa, et al (7) } \\
\text { López, et al (25) } \\
\text { Roth, et al (23) } \\
\text { Kato, et al (21) } \\
\text { Shaw (12) } \\
\text { Viet, et al (19) } \\
\text { Takeshima, et al (26) }\end{array}$ \\
\hline P14 & $\begin{array}{l}\text { Tumour suppressor } \\
\text { gene (related to } \\
\text { activity of p53) }\end{array}$ & Pro-apoptotic activity & $\begin{array}{l}\text { NR/12 } \\
\text { NR/80 (submucous fibrosis) }\end{array}$ & $\begin{array}{l}\mathrm{NR}^{\mathrm{a}} / \mathrm{NR} \\
\mathrm{NR} / 0\end{array}$ & $\begin{array}{l}\text { López, et al (25) } \\
\text { Takeshima, et al (26) }\end{array}$ \\
\hline MGMT & $\begin{array}{l}\text { DNA repair gene } \\
\left(\mathrm{O}^{6} \text {-methylguanine- }\right. \\
\text { ADN-methyltrans- } \\
\text { ferase })\end{array}$ & $\begin{array}{l}\text { Prevents } \\
\text { alkylation } \\
\text { mechanisms }\end{array}$ & $\begin{array}{l}\text { 33/NR (HNC) } \\
\text { 23/NR (HNC) } \\
\text { NR/56 (oral leukoplakia) } \\
\text { 46/57 (oesophageal c.) } \\
\text { 56.4/NR (OSCC) } \\
\text { 52/80 (OSCC) } \\
\text { 29/NR (OSCC) } \\
\leq 20 / \mathrm{NR} \text { (salivary gland c.) }\end{array}$ & $\begin{array}{l}48 / \mathrm{NR} \\
50 / \mathrm{NR} \\
\mathrm{NR}^{\mathrm{a}} / \mathrm{NR} \\
\mathrm{NR} / 9 \\
\mathrm{NR} / 68.18^{\mathrm{b}} \\
\mathrm{NR} / 73^{\mathrm{b}} \\
62.5 / \mathrm{NR} \\
\mathrm{NR} / \leq 15\end{array}$ & $\begin{array}{l}\text { Sanchez-Cespedes, et al (16) } \\
\text { Rosas, et al (18) } \\
\text { López, et al (25) } \\
\text { Roth, et al (23) } \\
\text { Kato, et al (21) } \\
\text { Sawhney, et al (28) } \\
\text { Viet, et al (19) } \\
\text { Lee, et al (29) }\end{array}$ \\
\hline DAP-kinase & $\begin{array}{l}\text { Tumour suppressor } \\
\text { gene }\end{array}$ & $\begin{array}{l}\text { Involved in apoptosis. } \\
\text { Inhibits appearance } \\
\text { of metastases }\end{array}$ & $\begin{array}{l}\text { 18/NR (HNC) } \\
\text { 33/NR (HNC) } \\
\text { 23.8/NR (HNC) } \\
\text { 27/NR (OSCC) }\end{array}$ & $\begin{array}{l}18 / \mathrm{NR} \\
60 / \mathrm{NR} \\
\mathrm{NR} / \mathrm{NR} \\
\mathrm{NR} / \mathrm{NR}\end{array}$ & $\begin{array}{l}\text { Sanchez-Cespedes, et al (16) } \\
\text { Rosas, et al (18) } \\
\text { Hasegawa, et al (7) } \\
\text { Shaw (12) }\end{array}$ \\
\hline E-cadherin & $\begin{array}{l}\text { Related to lymph } \\
\text { node metastasis } \\
\text { and cell invasion }\end{array}$ & $\begin{array}{l}\mathrm{Ca}^{2+} \text { dependent } \\
\text { molecule. Regulates } \\
\text { intercellular junction }\end{array}$ & $\begin{array}{l}\text { 36.3/NR (HNC) } \\
\text { 46/NR (OSCC) } \\
\text { 7/NR (OSCC) } \\
\leq 20 / \mathrm{NR} \text { (salivary gland c.) } \\
\text { 85.4/NR (OSCC) }\end{array}$ & $\begin{array}{l}\mathrm{NR} / \mathrm{NR} \\
\mathrm{NR} / \mathrm{NR} \\
\mathrm{NR} / \mathrm{NR} \\
\mathrm{NR} / \leq 15 \\
\mathrm{NR} / 33.3\end{array}$ & $\begin{array}{l}\text { Hasegawa, et al (7) } \\
\text { Shaw (12) } \\
\text { Viet, et al (19) } \\
\text { Lee, et al (29) } \\
\text { Yeh, et al (33) }\end{array}$ \\
\hline RASSF1A & $\begin{array}{l}\text { Tumour suppressor } \\
\text { gene (ras association } \\
\text { domain family 1A) }\end{array}$ & Ras modulation & $\begin{array}{l}\text { 7.5/NR (HNC) } \\
\text { 35/NR (salivary gland c.) }\end{array}$ & $\begin{array}{l}\mathrm{NR} / \mathrm{NR} \\
\mathrm{NR} / \leq 10\end{array}$ & $\begin{array}{l}\text { Hasegawa, et al (7) } \\
\text { Lee, et al (29) }\end{array}$ \\
\hline RAR- $\beta_{2}$ & $\begin{array}{l}\text { Receptor of } \\
\text { retinoic acid }\end{array}$ & $\begin{array}{l}\text { Cell growth } \\
\text { modulator. Regulates } \\
\text { transcription }\end{array}$ & $\begin{array}{l}\text { 66/53 (HNC) } \\
\text { 39/43 (oesophageal c.) } \\
\text { 46/NR (salivary gland c.) }\end{array}$ & $\begin{array}{l}\mathrm{NR} / 27^{\mathrm{b}} \\
\mathrm{NR} / 0 \\
\mathrm{NR} / \leq 15\end{array}$ & $\begin{array}{l}\text { Youssef, et al (30) } \\
\text { Roth, et al (23) } \\
\text { Lee, et al (29) }\end{array}$ \\
\hline CLDN3 & $\begin{array}{l}\text { Regulates close } \\
\text { intercellular } \\
\text { junctions }\end{array}$ & $\begin{array}{l}\text { Related to } \\
\text { apoptosis mechanisms }\end{array}$ & 69/29 (oesophageal c.) & $\mathrm{NR} / 0$ & Roth, et al (23) \\
\hline CRBP & $\begin{array}{l}\text { Apocellular retinol- } \\
\text { binding protein }\end{array}$ & $\begin{array}{l}\text { Participates in } \\
\text { binding of retinoic } \\
\text { acid with its receptor }\end{array}$ & 31/29 (oesophageal c.) & $\mathrm{NR} / 0$ & Roth, et al (23) \\
\hline MT1G & $\begin{array}{l}\text { Involved in } \\
\text { metabolism } \\
\text { of metals and } \\
\text { detoxifying } \\
\text { mechanisms }\end{array}$ & $\begin{array}{l}\text { Associated with } \\
\text { hepatic storage } \\
\text { of copper }\end{array}$ & 62/57 (oesophageal c.) & $\mathrm{NR} / 9$ & Roth, et al (23) \\
\hline
\end{tabular}


Table I. Continued.

\begin{tabular}{|c|c|c|c|c|c|}
\hline $\begin{array}{l}\text { Type of } \\
\text { gene }\end{array}$ & Function & Action mechanism & $\begin{array}{c}\% \text { Methylation in } \\
\text { tumour lesion/ } \\
\text { pre-cancerous lesion }\end{array}$ & $\begin{array}{l}\% \text { Methylation } \\
\text { in saliva/ } \\
\text { healthy mucosa }\end{array}$ & Refs. \\
\hline PRTFDC1 & $\begin{array}{l}\text { Tumour suppressor } \\
\text { gene (phosphoribosyl } \\
\text { transferase domain } \\
\text { containing 1) }\end{array}$ & $\begin{array}{l}\text { Associated with } \\
\text { pharmaceutical } \\
\text { metabolism }\end{array}$ & 17/NR (OSCC) & NR/NR & Suzuki, et al (34) \\
\hline
\end{tabular}

NR, not recorded. HNC, head and neck cancer; OSCC, oral squamous cell carcinoma. 'López, et al (25), $82 \%$ of patients were positive for the methylation of at least one of the studied genes in saliva samples, but the percentage corresponding to the methylation of each gene is not specified. ${ }^{b}$ Peritumoural healthy mucosa.

hereditary changes in gene expression that are not encoded in the DNA sequence. Thus, chemical modifications in DNA and associated proteins can alter gene expression without affecting the DNA sequence (9). One of the most important chemical changes is methylation (10).

Methylation is produced in cytosines of $\mathrm{CpG}$ dinucleotides (Cytosine and Guanine separated by phosphate) that are preferentially grouped (CpG islands) in promoter regions and the first exons of protein encoding genes. These cytosines are not methylated under normal conditions and methylation modifies their structure, preventing transcription factors from binding to the promoter region and therefore blocking the expression of certain genes. The methyl group is added to cytosine nucleotides of these specific areas by means of the DNA-methyltransferase enzyme, thereby inhibiting expression of this portion of the gene. These genes are usually related to cell growth, DNA repair, intracellular binding and metastasis inhibition, among others, which are active in normal cells but silenced in malignant cells. Non-methylation of $\mathrm{CpG}$ islands in the promoter region is related to high transcriptional activity (open lollipops, no methylation of promoter region), and hypermethylation is related to gene blockade (closed lollipops, abundant methylation of $\mathrm{CpG}$ islands of promoter region) (11).

It was previously thought that an alteration (mutation or deletion) of both alleles was necessary to block a tumour suppressor gene, but it has since been observed that a gene can be silenced by heterozygotic alteration of a single gene allele. Cancer, in common with autoimmune diseases and aging, may be mediated by the gradual accumulation of epigenetic changes (12).

Hypermethylation of $\mathrm{CpG}$ islands is very frequently observed in transformed cells in which apoptosis is not produced (13), and it has also been associated with inhibition of the transformation of certain tumour-suppressor genes (2). This aberrant methylation occurs during carcinogenesis despite the normal protection of $\mathrm{CpG}$ islands from this epigenetic change. Aberrant methylation of the DNA of some genes is a common characteristic of many human cancers, but the mechanism underlying this alteration has yet to be elucidated. Other epigenetic changes include histone deacetylation, which makes chromatin inaccessible to the transcription machinery and has a similar gene-blocking effect to that of methylation, and hypomethylation, which implies excessive gene expres- sion. However, the relationship of these processes to cancer has been less well studied (12).

DNA for the study of these alterations can be extracted not only from cells but also from sera, in accordance with the tumour site, e.g., sputum in lung cancer, saliva in oral cancer and urine in colorectal cancer. This is because the DNA in these fluids derives from apoptotic tumour cells or tumour cells that have passed to the blood without capacity to produce metastases. In fact, it has been reported that the amount of DNA in sera is 4-fold higher in cancer patients than in healthy patients (14) and 2-fold higher in patients with than without distant metastases (15). Higher serum DNA concentrations have also been found in patients showing good outcomes after radiotherapy (16).

\section{Epigenetic alterations in oral cancer and pre- cancerous lesions: p16 ${ }^{\mathrm{INK} 4 \mathrm{a}}$, MGMT, DAP-kinase, RAR $\boldsymbol{\beta}_{2}$, E-cadherin, other genes}

The effects of methylation have been studied in various genes over recent years, extracting genetic material from cells in tumours, pre-cancerous lesions, serum, or healthy tissue adjacent to the tumour. This is because methylation can be detected in tumours and pre-malignant lesions and even in clinically and histologically healthy tissue, suggesting that methylation may occur early in oral carcinogenesis and might serve as an early marker of the disease (17). Determination of the methylation status of promoter genes has proven useful for the detection of OSCC in samples of saliva and surgical tumour margins (18). Published studies have reported a correlation of $42 \%(16), 62.5 \%$ (19) and $65 \%$ (18) between methylation findings in tumour and saliva samples, and no serum DNA alterations have been found in patients who did not also show these changes in tumour DNA (18).

A positive result in serum DNA (loss of heterogeneity or presence of new alleles) was also reported to be a predictive factor for distant metastases, based on findings that were statistically significant despite a small sample size (20). In oral medicine, methylation has been analyzed in various types of sample: in head and neck tumours, focussing on the oral region and especially OSCC; in pre-cancerous lesions such as leukoplakia, lichen planus and different grades of dysplasia; and in healthy saliva and mucosa samples (to 
establish comparisons with disease states). Sample sizes have been highly variable. In the present review, we found study populations of 95 (16) or 80 patients with primary head and neck tumours (7) and others of only 14 patients with OSCC or severe dysplasia (19). Sample sizes are smaller in studies of sera or pre-cancerous lesions than in studies of tumours. These discrepancies in sample sizes and in the different media analyzed hamper comparisons among results and the confirmation of a clear relationship between methylation and carcinogenesis.

Hypermethylation has been investigated in numerous genes in an attempt to establish a clear link between this epigenetic mechanism and carcinogenesis. Certain genes appear to be of special importance in this respect, although results have varied widely in some cases and depending on the type of study (Table I).

p16INK4a. This tumour suppressor gene inhibits kinase-dependent cyclines and is vital for keeping the retinoblastoma protein in its active non-phosphorylated state. Various studies have reported $27-76 \%$ methylation of this gene in tumours versus the $0 \%$ obtained in healthy oral mucosa $(7,16,18,19,21,22)$. Interestingly, one study detected $72.73 \%$ methylation (21) in 22 samples of healthy peritumoural tissue, suggesting that p16 methylation may be an early event in carcinogenesis and might therefore serve as a prognostic and diagnostic marker. In studies on pre-cancerous lesions, it was reported that p16 methylation was not related to the malignant transformation of lichen planus (23) but was significantly associated with the malignization of leukoplakia, especially in relation to tobacco (but not alcohol) use (24). A correlation was also found between p16 methylation and higher-grade dysplasia $(18,23,25,26)$. However, another study of patients in whom p16 methylation was detected reported that the time interval between methylation and OSCC onset varied widely (0-70 months, mean of 18 months), suggesting that p16 methylation may not be correlated with the pathological status of the lesion (27). On the other hand, a higher level (up to 4-fold) of methylation was found in histologically healthy samples from patients previously treated for OSCC, indicating a greater predisposition to tumour recurrence (24). Studies of saliva samples from patients with head and neck cancer $(16,18,19)$ and with leukoplakia (25) reported 31.0-87.5\% methylation of p16 in serum DNA. These levels, which are higher than those obtained in tumours, may be explained by the up to 4-fold higher concentrations of serum DNA in cancer patients versus healthy individuals (14). Serum analysis therefore represents an effective methylation detection method that is non-invasive, unlike biopsies. However, these results were obtained in studies of cancer patients, except for one (25) in patients with pre-cancer (34 patients with leukoplakia) that also found significant levels in saliva. Finally, studies of hair follicles $(24,25)$ were able to establish that p16 methylation was related to the localization of leukoplakia onset. As in OSCC, p16 methylation was also studied in mucoepidermoid carcinoma of salivary glands (22), finding that the methylation $(34.3 \%)$ was not significantly related to the pathogeny of this cancer type, unlike the homozygous deletion of this gene.
MGMT ( $\mathrm{O}^{6}$-methylguanine-DNA methyltransferase). This DNA repair gene has been observed to be inactive in cancer. As in the case of p16, MGMT has been widely studied in different types of sample from OSCC and from head and neck cancer in general. Studies have detected MGMT methylation percentages of 23 to $56.4 \%$ in tumour tissue $(16,18,19,21,23,28)$ versus the $9 \%$ found in oral mucosa of healthy individuals (23). The data for salivary gland cancer are less clear: in the tumour, MGMT methylation of $<20 \%$ was observed in 5 cell lines and 69 human salivary gland carcinoma samples, while methylation of up to $15 \%$ was found in healthy mucosa (29). However, reports of MGMT methylation of 68-73\% in healthy perilesional tissue $(21,28)$ and of 56 and $80 \%$ in leukoplakia samples $(23,25,28)$ suggest that, as with p16, MGMT methylation may be related to an early stage of the lesion and might be useful as a prognostic or diagnostic factor. In fact, it was observed in lesions with a low-grade dysplasia and even in clinically normal oesophageal mucosa with no detectable histological lesion (23). Studies of saliva samples $(16,18,25,19)$ obtained methylation percentages of $48-62 \%$, indicating that saliva analysis is an effective method to detect methylation of this gene. Inhibition of MGMT was found to be related to an advanced stage of the disease, lymph node metastasis, a poor prognosis, tobacco use, and to increased genetic instability in pre-cancerous oral lesions (28).

DAP-kinase (death-associated protein kinase). This tumoursuppressor gene is implicated in apoptosis and potentially inhibits the appearance of metastases. For this reason, it has not been studied in pre-cancer or as a diagnostic factor. Methylation percentages of $18-27 \%$ have been reported in tumour tissue $(7,16,18)$, which are not very elevated levels, although a high correlation was found with the presence of lymph node metastases $(7,12,16,18)$. Findings on its presence in saliva samples from patients with head and neck cancer have ranged from 18 to $60 \%$.

$R A R \beta_{2}$ (retinoic acid receptor). RAR- $\beta_{2}$ is the most important tumour suppressor gene of the RAR $\beta$ family. Alterations in the gene that encodes the expression of this receptor have been found in various types of cancer and premalignant lesions. Suppression of RAR- $\beta_{2}$ function due to methylation was observed in $67 \%$ of head and neck cancer samples $>50 \%$ of head and neck tumour cell lines and pre-cancerous lesions, more frequently in the former, suggesting that methylation may increase during carcinogenesis (30). Furthermore, the prevalence was reported to increase with a higher grade of dysplasia (23). Olazs et al (31), among others, analyzed the effects of hypermethylation and loss of heterogeneity in genes that transcribe $\mathrm{RAR} \beta_{2}$ receptors, studying their role in retinoid therapy and chemoprevention. In their study of 89 primary head and neck tumours, methylation was the major cause of suppression of these receptors and was found in the tumour and as an early event in the carcinogenesis. RAR $\beta_{2}$ methylation was not associated with tumour localization, stage or metastasis but was related to higher age, apparently due to the longer contact time between carcinogenic elements and mucosa (31). It also appears to be significantly related to tumours with an aggressive phenotype and to a poor survival prognosis (29). 
E-cadherin. This transmembrane glycoprotein is involved in cell adhesion and has been related to the prognosis in invasive OSCC. Reports on the percentage methylation of the gene that encodes this protein range from 7 to $46 \%$ in patients with oral cancer $(7,12,19)$ and show a $>60 \%$ correlation with saliva samples (19). Its methylation is infrequent in salivary gland cancer (29). One study (32) determined the methylation of E-cadherin in seven cell lines of oral carcinoma, one of epidermoid cancer and one of malignant melanoma, and analyzed its association with the survival of motor neuron protein interacting protein 1 (SIP1). Previous studies had found that SIPI was closely related to the loss of E-cadherin expression and to the prognosis of cancer patients. However, the above study found that methylation of this gene was highly involved in the inhibition of E-cadherin in cancer cells, which usually express SPII at multiple levels, suggesting that the methylation blocked expression of the gene independently of the proteins. Finally, it was reported (33) that alterations in pre-cancerous lesions may include E-cadherin methylation, which was observed in $85.4 \%$ of OSCC samples and in perilesional healthy mucosa samples from $33.3 \%$ of the cases, with $12.5 \%$ of these showing the same degree of methylation as the cancerous lesion.

Other genes. Other tumour suppressor genes have been investigated in the past few years, including PRTFDC1, whose alteration is usually due to deletion or mutation. However, its inhibition in OSCC lesions suggests that it may also be affected by epigenetic processes. In a recent study, methylation of this gene was detected in $17 \%$ of OSCC lesions and was not found to be related to tobacco or alcohol use, gender, age or tumour stage (34).

RAS association family 1 gene (isoform RASSF1A), located at $3 \mathrm{p} 21.3$, has also been widely studied in this context, showing $7.5 \%$ methylation in head and neck cancer (7) and $35 \%$ methylation in salivary gland cancer (29). It has also been associated with aggressive tumours and shorter survival time (29).

Methylation of p14 and p15 genes has been studied in the setting of OSCC. In the case of p14, methylation was found in $12 \%$ of a group of patients with a history of the disease, suggesting its association with a later stage in tumour formation (25). Methylation of p15 was observed in $29 \%$ of OSCC patients (19).

Researchers are currently investigating the methylation of new genes, including PTEN, a tumour suppressor gene involved in the inhibition of migration and tissue invasion, and RUNX3 (Runt-related transcription factor 3), an important component of the TNF- $\beta$-induced tumour suppression pathway. PTEN was analyzed in 113 tumours and the corresponding healthy perilesional tissue samples, finding a $77.8 \%$ reduction in gene expression due to methylation. It was previously demonstrated that this gene is inactivated by mutations or transcription losses and that the silencing of this gene is probably related to tumour genesis in OSCC (35). RUNX3 has been related to neurogenesis and thymopoiesis, and a decreased RUNX3 expression implies a reduced sensitivity of the growth inhibition effect and a reduced TNF- $\beta$-induced apoptotic activity. One of the mechanisms by which this protein is reduced is by methylation of the $\mathrm{CpG}$ island and its gene expression. A study of 10 samples of healthy mucosa and 30 samples of OSCC with corresponding healthy perilesional mucosa detected methylation in $70 \%$ of OSCC samples and $53.3 \%$ of healthy adjacent mucosa samples, a non-significant difference. Methylation of this gene was not detected in any of the healthy mucosa control samples (36). There have also been recent studies on the methylation of other genes such as hMLH1 and hMSH2, which both participate in the DNA repair system (mismatch repair), concluding that their methylation may play a role in carcinogenesis and may be correlated with a tendency to develop multiple malignant lesions in the oral cavity (37).

\section{Sampling for methylation study}

Tissue samples. Samples are usually taken from pre-cancerous lesions, tumour lesions and/or healthy peritumoural tissue. Some authors use formalin-fixed and paraffinembedded tissue for pathology and immunohistochemistry studies, cutting it into $5-\mu \mathrm{m}$ sections, which are kept in gelatine capsules for haematoxylin-eosin staining $(26,28,36)$. Other authors freeze samples at $-80^{\circ} \mathrm{C}$ and cut them with a microtome $(16,18-22,27,31,38)$. Others have used both procedures in the same study, freezing tissue samples of normal mucosa, mild dysplasia, severe dysplasia and $\mathrm{OSCC}$ at $-70^{\circ} \mathrm{C}$ and cutting them into $5-\mu \mathrm{m}$ sections (haematoxylin-eosin staining) and fixing samples from healthy patients with alcohol and embedding them in paraffin (23).

Saliva samples. After a 1-min mouthwash with $10 \mathrm{ml}$ of distilled water, the patient expectorates into a sterile plastic tube that is then despatched to the laboratory. Samples are centrifuged at 2,500 rpm for $15 \mathrm{~min}$ and washed with phosphate-buffered saline $(18,25)$. Supernatants are decanted and cell residues are frozen at $-80^{\circ} \mathrm{C}$ in the same tubes $(16,20)$.

Some authors took a few hair roots from each patient and stored them at $-20^{\circ} \mathrm{C}$ to compare DNA of extraoral cells and examine the relationship of methylation with oral localization $(24,25)$.

Formaldehyde-fixed and paraffin-embedded tissues are a very good source for genetic analysis. The handling, fixation and post-extraction care of the tissues are highly important. Tissues are washed with ethanol to remove paraffin. However, formaldehyde fixation may affect DNA acids by increasing the $\mathrm{pH}$ of the tissue, preventing its use for genetic analysis (39). The genetic material from paraffin-embedded tissues fixed in formaldehyde for $>48 \mathrm{~h}$ is impaired (40).

The most effective method for DNA extraction from samples appears to be protease $\mathrm{K}$ digestion at $56^{\circ} \mathrm{C}$ for $3 \mathrm{~h}$ followed by denaturalization and treatment with phenol/ chloroform and alcohol precipitate $(19,20,25,40)$.

Methylation analysis technique is conducted with a methylation-specific PCR (MSP) described by Herman et al; it requires DNA treatment with sodium bisulphite to differentiate methylated and non-methylated bases (41). Methylight can also be used (42); it quantitatively analyses methylation using a fluorescence-based PCR method that allows various genes to be studied in several patients within 
$2 \mathrm{~h}$ (19). A novel technique known as methylation enrichment pyrosequencing (MEP) has been developed that overcomes the shortcomings of MSP, which tends to yield false positive results and is not reliable in samples with a low concentration of DNA and high number of cycles. Pyrosequencing avoids false positives; the treatment is controlled with bi-sulphate, and it has a high sensitivity and capacity to detect methylation in samples with a low DNA content (27).

\section{Relationship with other tumours}

Methylation of $p 16$, among other genes, has also been detected in $24 \%$ of hepatic carcinomas, and the lack of its expression has been associated with tumours with high- versus low-grade malignancy; therefore, it appears to be related to the malignant phenotype of this liver tumour (38). Methylation of DAP-kinase has been related to tumour spread and to lung cancer, leukaemia and lymphomas $(16,17,43,44) . M G M T$ is frequently inactivated in brain, lung and colorectal cancers and lymphomas (44), and suppression of $E$-cadherin is observed in invasive gastric carcinomas and in those with high-grade dysplasia (32). Roth et al reported that certain genes ( $p 16, M G M T$, DAP-kinase) were methylated in $>90 \%$ of a series of oesophageal carcinomas, concluding that methylation was a frequent event in the development of this cancer. They also found a tendency for methylation to increase with higher grade of epithelial dysplasia, with a more marked change between mild and severe dysplasia (23).

\section{Relationship with tobacco use}

In oral cancer, the methylation of p16 and E-cadherin appears to be related to the tobacco habit, since exposure to tobacco directly or indirectly induces damage to the $\mathrm{CpG}$ islands in certain genes, eliminating protective mechanisms or inducing DNA-methyltransferase activity. Hence, tobacco plays a major role in the methylation of these genes, and an earlier start and greater intensity (cigarettes/year) of the habit increase the likelihood of aberrant methylation of p16 and E-cadherin, respectively, in head and neck cancer. In contrast, no relationship has been found between gene methylation and alcohol use (7).

Methylation of p16 has also been detected in $1-15 \%$ of oral mucosa samples from healthy smokers with no history of pre-cancerous lesions $(18,45)$.

Methylation of p14 is especially frequent in pre-cancerous lesions associated with betel nut chewing and may reduce the normal transcription of $p 53$ (tumour suppressor gene associated with $p 14$ ). However, p16 methylation did not differ between betel chewers and non-chewers but did differ between tobacco smokers and non-smokers (24).

\section{Relationship with progression and malignization}

$M G M T$ has been detected in peritumoural oral mucosa and in epithelial hyperplasia and dysplasia, with a higher percentage methylation in the latter, suggesting that its methylation is an early event in oral carcinogenesis (28). Healthy mucosa of OSCC patients also presents methylation of MGMT and p16, which may therefore serve as disease markers. Methylation can be considered an event at the beginning of carcinogenesis that persists over time and gives rise to cell division, increasing the capacity for tumour recurrence in patients already treated for a primary tumour $(21,24,25)$.

It has also been reported that the methylation of genes encoding proteins that control intercellular binding and apoptosis (e.g., DAP-kinase, E-Cadherin, and CLDN3) may promote invasive tumours and increase the likelihood of metastasis $(16,17)$.

\section{Reversibility of methylation}

In contrast to genetic changes, changes at epigenetic level are potentially reversible. Consequently, methylation and acetylation inhibition could be studied as anti-cancer therapy. A potent specific inhibitor of methylation is 5-aza-20-deoxycytidine, which reverses methylation in vitro and has been used in the treatment of leukaemias and myelodysplasias. However, this inhibitor can also activate other genes that are silenced under normal conditions, resulting in new alterations that may not be beneficial for the patient. Nonetheless, there is interest in the fact that methylation blocks genes that confer chemoresistance to certain pharmaceuticals; for instance, protein caspase- 8 reactivates with 5-aza-20-deoxycytidine and restores chemotherapy sensitivity $(7,11,12,30,32)$. It has also been reported that retinoids may revert the carcinogenesis process by numerous mechanisms, including the modulation of epithelial differentiation and proliferation by gene expression regulation. One of their receptors is $\operatorname{RAR} \beta_{2}$, which is suppressed in early stages of head and neck cancer and whose restoration is associated with a clinical response to cancer (31).

\section{Conclusion}

Knowledge of the hypermethylation of certain genes may contribute to a deeper understanding of cancer. Hypermethylation is found in tumour lesions, cancer precursor lesions and in healthy mucosa, but in different percentages, so it has been proposed as a diagnostic and prognostic molecular marker to assed a higher risk of malignant lesion development. The genes that appear to be most implicated in malignant oral lesions are p16, MGMT, RAR $\beta_{2}$, E-cadherin and DAP-kinase based on this review. P16 and RAR $\beta_{2}$ are tumour suppressor genes involved in the cell cycle so the silencing of these genes would imply an impaired cell reproduction, MGMT is a DNA repair gene which is important to preserve the DNA integrity, and the last two genes participate mostly in the progression of OSCC to metastasis, as being the E-cadherin a cell-to-cell adhesion controller and DAP-kinase an apoptosis controller. However, further studies are necessary to verify the true usefulness of this process in the early diagnosis of pre-cancerous lesions and to determine them as related prognostic factors.

\section{References}

1. Oliver RJ, Dearing J and Hindle I: Oral cancer in young adults: report of three cases and review of the literature. Br Dent J 188: $362-365,2000$. 
2. Herman JG, Latif F, Weng W, Lerman MI, Ibar B, Liu S, Samid D, Duan DSR, Gnarra JR, Linehan WM and Baylin SB: Silencing of the VHL tumor-suppressor gene by DNA methylation in renal carcinomas. Proc Natl Acad Sci USA 91: 9700-9704, 1994.

3. Banoczy J, Gintner Z and Dombi C: Tobacco use and oral leukoplakia. J Dent Educ 65: 322-327, 2001.

4. Femiano F and Scully C: DNA cytometry of oral leukoplakia and oral lichen planus. Med Oral Patol Oral Cir Bucal 10: 9-14, 2005.

5. Scully C: Oncogenes, tumor suppressors and viruses in oral squamous carcinoma. J Oral Pathol Med 22: 337-347, 1993.

6. Kulkarni V and Saranath D: Concurrent hypermethylation of multiple regulatory genes in chewing tobacco associated oral squamous cell carcinomas and adjacent normal tissues. Oral Oncol 40: 145-153, 2004

7. Hasegawa M, Heather HN, Peters E, Ringstrom E, Posner M and Kelsey KT: Patterns of gene promoter methylation in squamous cell cancer of the head and neck. Oncogene 21: 4231-4236, 2002.

8. Balderas-Loaeza A, Anaya-Saavedra G, Ramirez-Amador VA, et al: Human papillomavirus-16 DNA methylation patterns support a casual association of the virus with oral squamous cell carcinoma. Int J Cancer 120: 2165-2169, 2007.

9. Feinberg AP and Vogelstein B: A technique for radiolabeling DNA restriction endonuclease fragments to high specific activity. Anal Biochem 132: 6-13, 1983.

10. Jones PA and Baylin SB: The fundamental role of epigenetic events in cancer. Nat Rev Genet 3: 415-428, 2002.

11. Worm S and Guldberg P: DNA methylation: an epigenetic pathway to cancer and a promising target for anticancer therapy. J Oral Pathol Med 31: 443-449, 2002.

12. Shaw R: The epigenetics of oral cáncer. Int J Oral Maxillofac Surg 35: 101-108, 2006.

13. Antequera F, Boyes J and Bird A: High levels of de novo methylation and altered chromatin structure at $\mathrm{CpG}$ islands in cell lines. Cell 62: 503-514, 1990.

14. Shapiro CM, Bitran JD and Shapiro RA: Remission of metastatic adenocarcinoma of the colon. JAMA 250: 2503-2504, 1983.

15. Leon SA, Shapiro B, Sklaroff DM and Yaros MJ: Free DNA in the serum of cancer patients and the effect of therapy. Cancer Res 37: 646-650, 1977.

16. Sánchez-Céspedes M, Esteller M, Wu L, et al: Gene promoter hypermethylation in tumors and serum of head and neck cancer patients. Cancer Res 60: 892-895, 2000.

17. Ha PK and Califano JA: Promoter methylation and inactivation of tumour-suppressor genes in oral squamous-cell carcinoma. Lancet Oncol 7: 77-82, 2006.

18. Rosas S, Kock W, Carvalho MG, et al: Promoter hypermethylation patterns of p16, $\mathrm{O}^{6}$-methylguanine-DNA-methyltransferase and death-associated protein kinase in tumours and saliva of head and neck cancer patients. Cancer Res 61: 939-942, 2001.

19. Viet CT, Jordan RC and Schmidt BL: DNA promoter hypermethylation in saliva for the early diagnosis of oral cancer. J Calif Dent Assoc 35: 844-849, 2007.

20. Nawroz H, Koch W, Anker P, Stroun M and Sidrannsky D Microsatellite alterations in serum DNA of head and neck cancer patients. Nat Med 2: 972-974, 1996.

21. Kato K, Hara A, Kuno T, et al: Aberrant promoter hypermethylation of p16 and MGMT genes in oral squamous cell carcinoma and the surrounding normal mucosa. J Cancer Res Clin Oncol 132: 735-743, 2006.

22. Guo XL, Sun SZ, Wang WX, Wei FC, Yu HB and Ma BL: Alterations of p16 $6^{\mathrm{INK} 4 \mathrm{a}}$ tumour suppressor gene in mucoepidermoid carcinoma of the salivary glands. Int J Maxillofac Surg 36: 350-353, 2007

23. Roth M, Abnet CC, $\mathrm{Hu} \mathrm{N}$, et al: p16, MGMT, RAR $\beta_{2}, \mathrm{CLDN}_{3}$ and MT1G gene methylation in esophageal squamous cell carcinoma and its precursor lesions. Oncol Rep 15: 1591-1597, 2007.

24. Ruesga MT, Acha-Sagredo A, Rodríguez MJ, et al: $\mathrm{p} 16^{\mathrm{INK} 4}$ promoter hypermethylation in oral scrapings of oral squamous cell carcinoma risk patients. Cancer Lett 250: 140-145, 2007.

25. López M, Aguirre JM, Cuevas N, et al: Gene promoter hypermethylation in oral rinses of leukoplakia patients-a diagnostic and/or prognostic tool? Eur J Cancer 39: 2306-2309, 2003.
26. Takeshima M, Saitoh M, Kusano K, et al: High frequency of hypermethylation of p14, p15 and p16 in oral pre-cancerous lesions associated with betel-quid chewing in Sri Lanka. J Oral Pathol Med 37: 475-479, 2008.

27. Hall GL, Shaw RJ, Field EA, et al: P16 promoter methylation is a potential predictor of malignant transformation in oral epithelial dysplasia. Can Epid Biomarkers Prev 17: 2174-2179, 2008.

28. Sawhney M, Rohatgi N, Kaur J, et al: MGMT expression in oral pre-cancerous and cancerous lesions: correlation with progression, nodal metastasis and poor prognosis. Oral Oncol 43: 515-522, 2007

29. Lee ES, Issa JP, Roberts DB, et al: Quantitative promoter hypermethylation analysis of cancer-related genes in salivary gland carcinomas: comparison with methylation-specific PCR technique and clinical significance. Clin Cancer Res 14: 2664-2672, 2008.

30. Youssef EM, Lotan D, Issa JP, et al: Hypermethylation of the retinoic acid receptor- $\beta_{2}$ gene in head and neck carcinogenesis. Clin Cancer Res 10: 1733-1742, 2004.

31. Olasz J, Juhász A, Remenar E, et al: RAR $\beta 2$ suppression in head and neck squamous cell carcinoma correlates with site, histology and age. Oncol Rep 18: 105-112, 2007.

32. Maeda G, Chiba T, Aoba T and Imai K: Epigenetic inactivation of E-cadherin by promoter hypermethylation in oral carcinoma cells. Odontology 95: 24-29, 2007.

33. Yeh KT, Shih MC, Lin TH, et al: The correlation between CpG methylation on promoter and protein expression of E-cadherin in oral squamous cell carcinoma. Anticancer Res 22: 3971-3976, 2002.

34. Suzuki E, Imoto I, Pimkhaokham A, et al: PRTFDC1, a possible tumor-suppressor gene, is frequently silenced in oral squamous-cell carcinomas by aberrant promoter hypermethylation. Oncogene 26: 7921-7932, 2007.

35. Kurasawa Y, Shiiba M, Nakamura M, et al: PTEN expression and methylation status in oral squamous cell carcinoma. Oncol Rep 19: 1429-1434, 2008.

36. Gao F, Huang C, Lin M, et al: Frecuent inactivation of RUNX3 by promoter hypermethylation and protein mislocation in oral squamous cell carcinomas. J Cancer Res Clin Oncol 135: 739-747, 2009.

37. Czerninsky R, Krichevsky S, Ashhab Y, Gazit D, Patel V and Ben-Yehuda D: Promoter hypermethylation of missmath repair genes, hMLH1 and hMSH2 in oral squamous cell carcinoma. Oral Diseases 15: 206-213, 2009.

38. Huang J, Shen W, Li B, Liao S, Zhang W and Cheng N: Molecular and inmunohistochemical study of the inactivation of the p16 gene in primary hepatocellular carcinoma. Clin Med J 31: 443-449, 2000.

39. Santos S, Sá D, Bastos E, et al: An efficient protocol for genomic DNA extraction from formalin-fixed paraffin-embedded tissues. Res Vet Sci 86: 421-426, 2008.

40. Ong MM, Ginzinger DG, Dekker N, et al: Effect of duration of fixation on quantitative reverse transcription polymerase chain reaction analyses. Mod Pathol 15: 979-987, 2001.

41. Herman JG, Graff JR, Myöhänen S, Nelkin BD and Baylin SB: Methylation-specific PCR: a novel PCR assay for methylation status of CpG islands. Proc Natl Acad Sci USA 93: 9821-9826, 1996.

42. Eads CA, Danenberg KD, Kawakami K, et al: MethyLight: a high-throughput assay to measure DNA methylation. Nucleic Acids Res 28: E32, 2000.

43. Inbal B, Cohen O, Polak-Charcon S, Kopolovic J, Vadai E, Eisenbach L and Kimchi A: DAP kinase links the control of apoptosis to metastasis. Nature 13: 180-184, 1997.

44. Esteller M, Sanchez-Cespedes M, Rosell R, Sidransky D, Baylin SB and Herman JG: Detection of aberrant promoter hypermethylation of tumor suppressor genes in serum DNA from non-small cell lung cancer patients. Cancer Res 59: 67-70, 1999.

45. Von Zeidler SV, Miracca EC, Nagai MA and Birman EG: Hypermethylation of the p16 gene in normal oral mucosa of smokers. Int J Mol Med 14: 807-811, 2004. 